\title{
Çizgi, Renk ve Leke Bağlamında Zeki Faik İzer Eserleri
}

\section{Özet}

1950'li ve 1960'll yıllarda Modern Türk Resmi'nin temsilcisi Zeki Faik İer; ritmik ve dinamik olan eserleriyle ön plana çıkmıştır. Sanatçının üslubunda genel tavır olarak bașlangıçta kübist ve geometrik etkiler görülürken, 1950 'li yıllarda soyut dışavurumcu ve lekeci eğilimler görülmektedir. Zeki Faik izer'in eserini tanımlayan öğeler arasında ritim, devinim ve dinamizm yer almaktadır. Zeki Faik İzer eserlerinde coșkulu anlatım diliyle ve zaman zaman müziğin etkisiyle dinamik ve hareketli eserler eserlerinde coşkulu anlatım diliyle ve zaman zaman müziginin etkisiyle dinamik ve hareketli eserler timsel bir yöntemle incelenmiştir. D Grubu ressamları içinde yer alarak Türk Resim Sanatinın kimlik oluşumuna katkıda bulunan Zeki Faik Izer'in üslubu, üslubunun kaynakları ve zaman içerisindek değişimi gözlemlenmiş ve sanatçıını ilerleyen dönemlerinde daha çok resmin temel öğelerinden çizgi, renk ve lekeyi yoğun olarak ön plana çıkardığı tespit edilmiștir. Özellikle bu öğeleri öne çıkarırken lirik ve rastlantısal hareketlerle eserlerini oluşturduğu, eser bütünlüğ̈ünde içerikten çok biçimsel öğeleri ve rastlantısal hareketlerle eserlerini oluş
ön planda tuttuğu sonucuna varılmıştır.

Anahtar Kelimeler: Türk Resmi, Non-figüratif Resim, Lirizm, Ritim, Dinamizm

\section{ZEKI FAIK IZER WORKS}

\section{IN THE CONTEXT OF LINE, COLOR AND STAIN}

\section{Abstract}

Zeki Faik Izer, the representative of Modern Turkish Painting in the 1950s and 1960s; he came to the fore with his rhythmic and dynamic works. While the general attitude in the style of the artist was initially cubist and geometric effects, abstract expressionist and blotchy tendencies were observed in the 1950s. Rhythm, dynamism and dynamism are among the elements that define Zeki Faik Izer's work.Zeki Faik izer created dynamic and dynamic works in his works with his enthusiastic narrative language and occasionally with the effect of music. In the research, the literature about Zeki Faik language and occasionally with the effect of music. In the research, the literature about Zeki Faik Zeki Faik İzer, who contributed to the formation of identity of Turkish Painting by being among the painters of the D Group, has observed the style, sources of his style and the change in time, and it has been determined that the artist heavily emphasized lines, colors and stains, which are among the basic elements of the painting.lt was concluded that especially while highlighting these elements, he created his works with lyrical and random movements, and prioritized formal elements rather than content in the integrity of the work.

Keywords: Turkish Painting, Non-figurative Painting, Lyricism, Rhythm, Dynamism 


\section{Giriş}

Eserlerinde coşkulu, ritmik ve dinamik etkileri bir arada barındıran Zeki Faik İzer; yurt dışı atölye deneyimleri ve Sanayi Nefise yıllarındaatölye hocalarının etkisi ile dışavurumcu etkilerin ağır bastığı eser üretimlerinde bulunmuştur. Belirli kavramlar aracilığıyla gelişen eserlerinin genelinde farklı üslup ve dönemlere ait özellikleri bir arada görmek mümkündür. Zaman zaman izlenimci, fovist ve dışavurumcu esintilerle eserlerin bütününde karşılaşılmaktadır.Tansuğ'un da belirttiği gibi Zeki Faik İzer, İbrahim Çallı atölyesinde öğrenim gördükten sonra eğitimine Paris'te devam etti;

1905 'te İstanbul'da doğdu. 1923'te Sanayi Nefise Mektebi'ne girdi ve İbrahim Çallı atölyesinde öğrenim gördü. 1928'de Paris'e giderek A. Lhote ve Othon Friesz'in atölyelerinde çalıştı. Yurda dönünce Gazi Eğitim Enstitüsü'ne resim öğretmeni olarak atandı (1932). "D Grubu"nun kuruluşuna katıldı (1933). 1934'te Paris'e giderek eski ustaların çalışmalarının kopyalarını yaptı. Yurda dönüşünde Güzel Sanatlar Akademisi Süsleme Sanatları Atölyesinde öğretmen olarak görev aldı. Akademi Müdürlüğü yaptı (1948-1952). Uluslararası Modern Sanat Sergisindeki (UNESCO, Paris 1946) Türk resmine ait bölümü, Ceunuschy Sergisi'ni (Paris'te Nurullah Berk'le, 1947) düzenledi. 1951'de Türk Sanat Tarihi Enstitüsü'nü kurdu. Uluslararası Modern Resim Sergisi'nde (Brüksel) Cevat Dereli'yle birlikte Türkiye'yi temsil etti. Guggenheim Uluslararası Sergisi'ne Türkiye birincisi olarak katıldı. En tanınmış eserleri șunlardır: İnkılap Yolunda, Dolmabahçe Sarayı, Büyük Balık, Akdeniz Mitolojisi. Zeki Faik İzer "D Grubu"nu oluşturan sanatçılar arasında serbest soyutlama fantezilerini en çok benimseyen bir ressam olarak karşımıza çıkmaktadır (Tansuğ 2003: 377-378).

Andre Lhote ve Othon Friesz atölyelerinde eğitim gören sanatçı; “D Grubu" içerisinde çalışmalarını sürdürmüştür. Başlangıç yıllarında kübist daha sonra gözlemci, dışavurumcu ve lekeci duyarlılığı olan soyut eserler üretmiştir. Zeki Faik İzer'in ritmin, müziğin ve dansın etkilerinin hakim olduğu eserleri görülmektedir.

Müzik-Dans temalı resimlerinde yarı izlenimci ve fov etkileri görülmekle birlikte boyanın rahatça kullanıldığı ve lokal renklerden uzaklaşıldığı ve bir kısım dışavurumcu özelliklerin belirginleşmeye başladığı gözlemlenir. İzer'in parçalanmış renkli figürleri içeren resim anlayışında 1946'lardan sonra dışavurumcu soyutlamayla ilgili bir aşamaya doğru bir yöneliş izlenir (Akdeniz, 1990: 70).

Zeki Faik İzer resminde desen ana öğeler arasında yer almaktadır. Desenlerdeki deforme olmus figürler biçimsel lekelere ve renklere dönüşmektedir. Özellikle 1950'li yıllarda figürsüz ve soyut üretimlerde bulunarak, rengin ve lekenin ön plana çıktığı eserler üretmiştir.Lirik soyut ve non-figüratif eserlerinde canlı renklerle oluşturulan yüzeyler ritimle karmaşadan çok bir düzen arayışındadır. Hareketli olan fırça vuruşları ise çizgi ve lekelerle ön plana çıkmaktadır. Özellikle Türk Resminde 1950'li yıllarda Sezer Tansuğ'un da belirttiği gibi soyut eğilimleri ile öne çıkan öncü kuşak sanatçıları arasında yer almaktadır;

Soyut resmin Türk sanatçılar tarafından pratiğine 40'lı yılların sonu ya da 50'li yılların başında İstanbul, Ankara ve Paris'te başlanmıştır. Paris'te Hakkı Anlı, Nejat Devrim, Selim Turan ve Abidin Dino'nun yanısıra, Fahrünisa Zeid ve Mübin Orhon'un da bu akıma uygun işlere yöneldiği anımsanabilir. İstanbul çevresinde bir süre sözcülüğü Nuri İyem'in üstlendiği soyut çalışmalara Zeki Faik İzer, Sabri Berkel, Ferruh Başağa ve sonraları Adnan Çoker gibi akademiye bağlı sanatçılar yönelmiştir. Bu ressamlar figürsüz soyut resimden hiç kopmayan bir ısrarı da sürdürmüşlerdir (Tansuğ, 1997 184).

Türk Resim Sanatı'nda 1950'li yıllarda gerçekçi, izlenimci ve kübist eğilimler yerini soyut eğilimlere bırakmıştır. Özellikle akademik olan sanat anlayışı yerini bireysel ve özgür kimlik arayışlarına bırakmıştır. Türk Sanatı'nda görülen bu değişiklikler sadece Türk Resim Sanatı'nda değil, mimari ve edebiyatta da kendini göstermistir. Türk Resim Sanatı'nda non- figüratif eğilimlerin yanı sıra bir grup sanatçı geleneksel sanat yaklaşımını ve yerelliği de benimsemiştir. Non-figüratif eserler üreten sanatçılar ise güncel olan sanatı yakalama çabası ve ifadeci fırça kullanımı ile objeyi tuvalden çıkarmışlardır. Bedri Rahmi Eyüboğlu ve Adnan Turani yerellikle soyut anlayışı bütünleyen eser üretimlerinde bulunurken, Sabri Berkel daha geometrik, soyut, leke ve biçimlerden oluşan kompozisyonlara ağırlık vermiştir. Abidin Elderoğlu ve Şemsi Arel ise kaligrafik soyuta yönelirken, Zeki Faik İzer daha ritmik olan renk ve fırça hareketleri ile lirik soyut üsluba yönelmiştir.

Resim sanatımızın 1950'li yıllardan bu yana gelişmesi, diğer sanat ve edebiyat alanlarında görülen tavır ve yaklaşım hareketleriyle paralellik gösterir. Garip ve özellikle ikinci yeni hareketleri, şiir sanatı alanında bu paralel değişimin çarpıcı bir örneğini oluşturur. Mimarlıkta modern teknolojinin, kentleşme olgusu içinde yapı düzen ve işlevlerini belirleyen katkısı, birim değeri taşıyan işlevsel öğelerle çağdaş kompozisyona ulaşma yönünden diğer bir paralel gelişmeye işaret eder. Çizgi ve rengin belirli form klişelerinden sıyrılarak yepyeni düzenler ve yeni humor fantezilerine ulaşma çabasını ortaya koyduğu grafik ya da illüstratif yaklaşımlar bile bu tür gelişmenin paralelinde bulunurlar (Tansuğ, 1995: 7).

Nuri Iyem, Turgut Zaim ve Malik Aksel yerellikle birleştirdikleri somut figürleri toplum ve toplumun gerçekliğini yansıtan bir bakış açısıyla eser üretiminde bulunmuşlardır. Nejat Devrim, Selim Turan veFahrünissa Zeid ise daha lirik olan sanatsal deneyimlere eserlerinde yer vermektedir. Avru- 
pa'da yaşayarak soyut işler üreten sanatçılar Türkiye'ye gelerek lirik soyut alanında eserler üretmişlerdir. Soyutlamalar biçimsel niteliklerle birlikte ritim ve dinamizm kavramlarının öne çıkmasıyla oluşmaktadır.

Paris'te yaşayan Nejat Devrim, Selim Turan, Fahrünisa Zeid'in soyut çalışmaların göbeğinde bu akıma katılmalarının yanısıra, Türk plastik sanat çevrelerinde gerek akademi içi, gerekse dışında bu akım Zeki Faik İzer, Nuri İyem gibi sanatçılar tarafından büyük ölçüde destekleniyor. Fakat soyut sanatın yerel ulusal geleneklerin özümsendiği "somut" bir temele oturması gerektiği hakkındaki görüşler, olaya genel olarak biçim ve yüzeysel doku açısından yaklaşan sanatçılarla tartışmalara neden oluyor. Fakat bu arada, soyut resme yönelik resim çabalarının temelinde bazen renk unsuruna ağırlık kazandırmış olan figüratif eğilimlerin bulunduğuna dikkat çekilmelidir (Tansuğ, 2003: 251).

Bedri Rahmi Eyüboğlu genellikle soyut eserleriyle yerel motifleri birlestirirken, Zeki Faik İzer, ritmik renk ve fırça vuruşlarını kullanır. Sabri Berkel ise, daha düz ve sade olan renk ve biçim özelliklerini geometrik soyut olarak tuval yüzeyinde kullanmaktadır. Nuri lyem, Turgut Zaim ve Malik Aksel yerellikle birleştirdikleri üslupların daha toplumsal gerçekçi ve somut temele oturtmaktadır. Nejat Devrim ve Selim Turan ise daha lirik olan sanatsal deneyimler oluşturmaktadır.

1971-1984 yılları arasında sürekli olarak yaşadığı, gözlem ve duyumlarını geliştirdiği, çalışmalarını sürdürdüğü Paris'te, Zeki Faik İzer, daha önce Türkiye'de başlattığ soyut çalışmalarının izinde yürürken, seçmiş olduğu yolun, bulunduğu ortamda kendini haklı çıkaran bulgulara açık seçeneklerle dolu olduğunu görmüştü. Bu yönde bir çakışmanın, sanatına kazandıracağı değerleri saptamanın keyifli ve özverili akışına kendini kaptırarak, birbiri arkasına desenler çizdi, tuvaller boyadı. Onun resimlerin yan yana koyup baktığımızda, birbirinden türemiş olan bu çalıșmaların, ortak bi sorunsallık çevresinde düğümlendiğine, sonra da bu düğümün kendiliğinden çözülüp açıldığına tanık oluyoruz (Özsezgin, (t.y.): 120).

Zeki Faik İzer, 1960 sonrası figürsüz soyutlamaya yönelerek, biçim ve lekenin ağır bastığı tekrar eden formlar, canlı renkler ve onları dengeleyen nötr renklerle oluşturulmuş fonlara eserlerinde yer vermektedir. Sadece tek renkten oluşan fonlar, bazen daha belirleyici olan renkli motiflerle tuval yüzeyinden çıkmaktadır. Yüzeyde derinliğin ortadan kalktığı lekeci anlayışla biçimlendirilen eserler; içgüdüsel lirik non-figüratif renk deneyselliği ile devam etmektedir.

\section{Zeki Faik İzer Eserlerinde Lirik ve Dinamik Eğilimler}

Zeki Faik İer eserlerini tanımlayan kavramlar arasında coşku, devinim, ritm ve dinamizm kavramlarını saymak mümkündür. Sanatçının eserlerinde içgüdüsel biçim bozma, gerçeklikten sıyrılma ve gerçekliğin bireysel yorumlanmış haliyle karşılaşılmaktadır. Sanatçı dıs gerçeklikte yer alan temel konuları, portreleri, figürleri ya da peyzajları içselleştirerek başka formlara dönüştürmektedir. Yapay ve dekoratif görünen çizgiler yerine rengin araç olarak kullanıldığı eserlerinde Zeki Faik Izer, ruhsal olarak kendini daha dışavurumcu ve dinamik renkler aracilığılla ifade etmektedir.

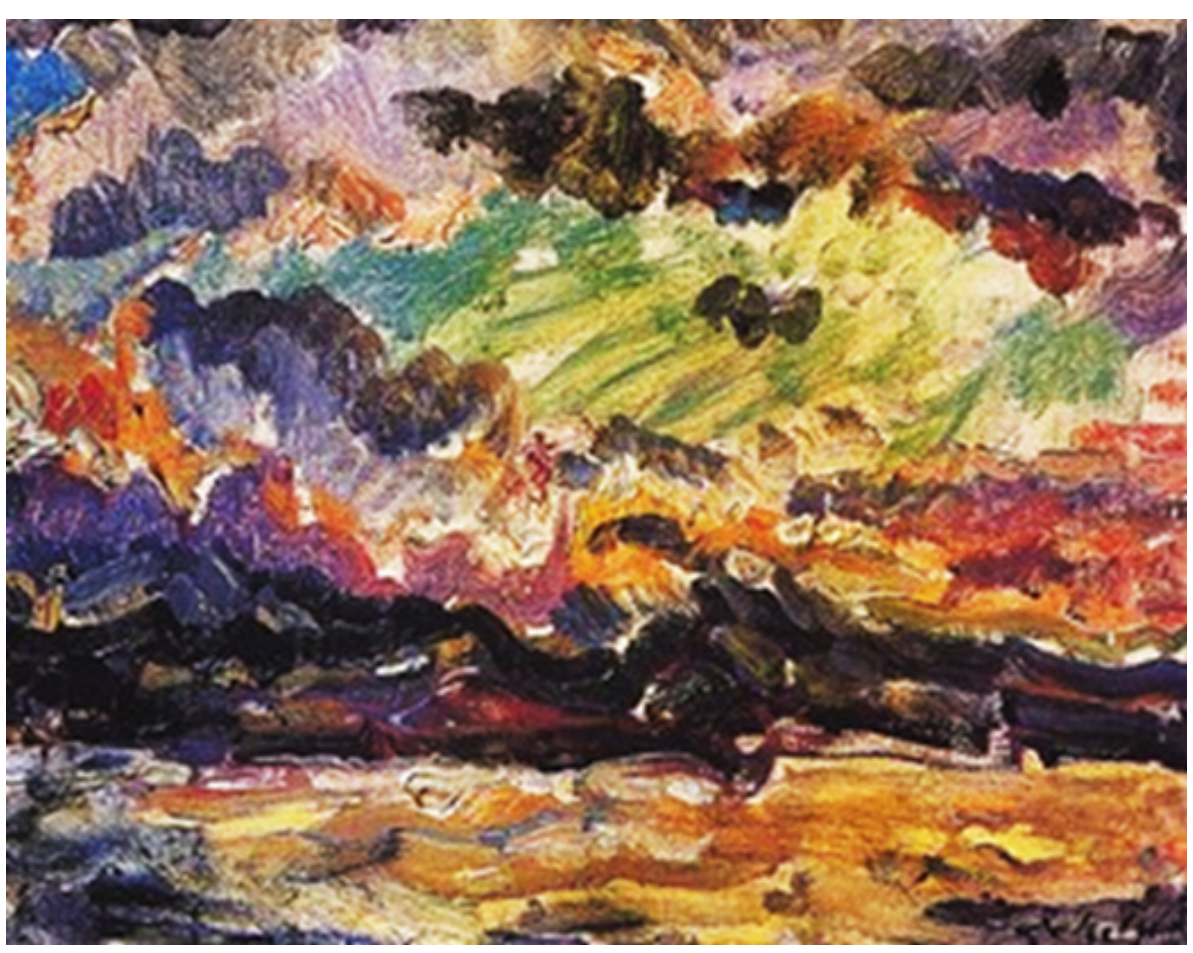

Görsel I. Zeki Faik İzer, “Büyükada’da Lodos”, 1968, Tuval üzerine yă̆lı boya, 33×40cm

Zeki Faik İzer dışavurumcu öznel arayışlarla, içgüdüsel hareketlerle, sezgi ve yetilerini dinleyerek ürettiği eserlerinde, kendi öz üslubunu, tekniğin ve biçimlerini oluşturmaktadır. İçsel duygu hareketleriyle biçim çarpıtma ve bozmalarınınetki ve izleri sanatçının eserlerinde hissedilmektedir. Sanatçının "Büyükada'da Lodos" isimli eseri; fırçanın serbestçe oluşturduğu lekeler, ritmik bir devinime dönüşen boya dokuları ve devinen leke bütünlüğü ile soyut olan dışavurumcu etkilerle oluşturulmuştur. Özellikle sıcak 
ve soğuk renk birliktelikleri resimdeki lirik hareketliliği de dengelemektedir. icçsel duyguların dışavurumu, biçimlerin reel olan dünyadan kaybolarak sanatçının kendi realitesinde var olmasına olanak sağlamaktadır. Reel dünyanın gerçekliklerinden sıyrılan biçimler; resmin genel bütünlüğü içerisinde yer alarak kendi öz biçimselliklerini korumaktadırlar. Zeki Faik İzer'in eserlerinde dinamizm ve lirik olan fırça kullanımları biçimlerin önüne geçerek daha ön planda yer almaktadır. Renkler ise bu ritmik ve devinen hareketliliğe yardımcı olarak ikinci planda yer almaktadır. Eserlerinde çoğunlukla çizginin devinimleri ve hareketli yapısı soyut resmin dengeleri açısından belirli bir öneme sahip olmaktadır. Çizgilerin iniş çıkışları, kompozisyon içerisindeki tanımlamaları, ifadesel bir dil içermektedir. Klee'nin belirttiği gibi;

Çizginin belirli oranları, ton değerleri skalasında tonların belirli kompozisyonları, renklerin belirli armonileri kendileriyle birlikte o anda oldukça ayırt edici önemli anlatım değerleri taşır. Örneğin çizgisel oranlar açılarla ilgilidir; düz ve yatay olanların aksine açısal ve zigzag hareketler aynı şekilde kontrast oluşturan anlatım tınılarına ulaşır. Benzer şekilde bir kontrast kavramı iki çizgisel konstrüksiyon biçimi ile verilebilir, biri sıkıca birleştirilmiş bir yapıdan, diğeri seyrek olan dağılmış çizgilerden oluşur (Klee, 2007: 37).

Resimsel lirizm, içsel duyguların dışavurumudur. Sanatçının fırçaları ve renkleri aracılığıyla bu duyguların temsili karşımıza çıkmaktadır. Özellikle fırçaların soyut eserlerdeki ritmik titreşimleri, başka renklerle olan birliktelikleri, tesadüfi gerçekleşen renk buluşmaları, sonsuz devinim Zeki Faik İzer eserlerinde dikkat çekmektedir. Dıs dünya nesnelerinin simgeleștiği görüntü serüveni, sanatçının tuvalinde bir mücadeleyle renkli nesne temsillerinin deneysel pratikleri, inişli ve çıkışlı biçimlere ve lekelere dönüşmektedir.

Zeki Faik İzer'in "Büyükada'da Poyrazlı Gün" isimli eserinde ise lirik fırça vuruşları ve ritmik renklerin coşkulu bir anlatımına tanıklık etmekteyiz. Özellikle Poyrazı bir gün olmasına rağmen sanatçı eserinde renklerin canlılığından ve coşkusundan ödün vermemektedir. İçsel heyecan ve coşku dili sanatçının genel eser diliyle rahatlıkla izlenmektedir. Çoğu eserde devam eden ritmik duyarlılık ve coşkulu anlatım, çoğu zaman bütünsel anlatımın geneline de yansıyarak büyük küçük olan resim dengelerini ve kurallarını da yok etmektedir.

Formların uygulanabilirliği, organik fakat ruhsal varyasyonları, resimdeki hareketleri, somuta ya da soyuta olan eğilimleri, bireysel olarak ya da bir bütünün parçaları olarak karşılıklı ilişkileri, ayrıca, bir resimdeki farklı unsurların uyumu ya da uyuşmazlı̆̆ı, grupların ele alınış şekli, örtülü ve açıkça ifade edilmiş çekiciliklerinin birleşimleri, ritmik ya da ritimsiz, geometrik ya da geometrik olmayan formların kullanıışı, birliktelikleri ya da ayrılıkları-tüm bunlar, resimdeki kontrpuanın malze- mesidir (Kandinsky, 2005: 94).

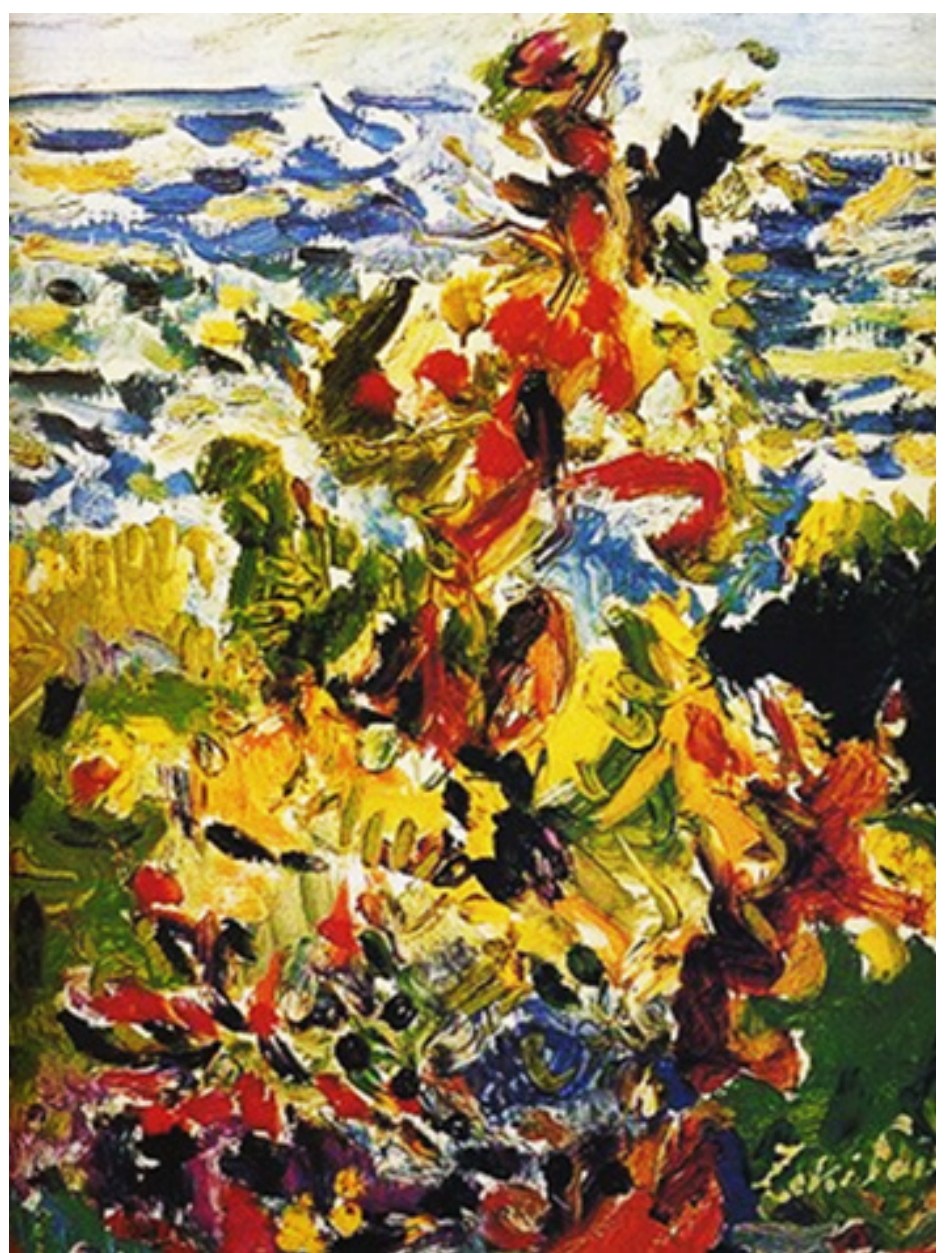

Görsel 2: Zeki Faik İzer, “Büyükada’da Poyrazlı Gün”, 1969, Tuval üzerine yağlı boya, $45 \times 38 \mathrm{~cm}$

Zeki Faik İzer resminin temel öğeleri olan çizgi, renk ve leke oluşumunda şüphesiz Akademi yıllarında etkisinde olduğu İbrahim Çallı ve Hikmet Onat'ın izleri de sezilmektedir. Organik olan soyut anlatımlarında ise Manessier ve Bazain etkisinde kalır. Renk arastırmalarında, serbest ve renkçi bir anlayışla, Matisse'in renkçi tavrı, fovistlerin lekeciliği de hissedilmektedir. Ayrıca eserlerde biçimlerin kenarlarında izlenen beyaz boşluklar sanatçının eserlerinin ifadeci ve modern yapısına uyum sağlamaktadır. 


\section{Zeki Faik İzer Eserlerinde İzlenen Müzik Etkisi}

İçsel duygu hareketleri ile dış dünyadaki sürecin ve yaşanılan deneyimlerinizlerinin duyusal aktarımına olanak sağlayan Zeki Faik Izer eserleri; yüzeylerde inip çıkan enerjiler ve duygu yansımaları ile karşılaşmamızı sağlamaktadır. Çizginin ve rengin üstlendiği görevler her eserde farklılaşmaktadır, her iki öğe de dışavurumu yansıtan birer araçsal nitelik olarak karşımıza çıkmaktadır. Zeki Faik İzer eserleri, polifonik etkilerle birlikte huzursuzluk, bunalım ve acının yerine daha çok neşe ve enerji içerir. Dışavurumculuğun üstüne inşa edilen Soyut Dışavurumculuk, Informal Sanat ve lekeciliğe yaklaşan çizimleri ileZeki Faik İzer 1960'lı yıllarda eserlerinde daha çok müzik, renkve ritim ilişkisi üzerinde durarak üretimlerde bulunmuştur.

Resimlerde renk katmanları nasıl yer yer saydamlaşıyor, altından başka renk, ışık ya da bir leke belirginleşerek derinlik oluşturuyorsa bu müzikte de üst üste gelen tını renkleri derinlik oluştururlar, mekan yaratırlar. Tınılarının sürelerinin değişik olması, biri daha sürerken ötekinin kesilmesi, yeniden başlaması vb. dinleyiciyi resimlerde olduğu gibi hem bir boşluğa, derinliğe hem de zaman ötesine çeker. Bir başka yakınlık parça-bütün ilişkisidir. Bu müzik geleneksel müzikte olduğu gibi, birbirleriyle ilişkilendirilen parçaların bir araya gelmesinden, bütünleșmesinden oluşan bir müzik değildir. Bestenin çıkış noktası tını renklerinin bütünlüğüdür(İpşiroğlu, 2000: 109).

Zeki Faik İzer eserlerinde kaybolan derinlik etkisi ile eserlerde arka fon ayrımı ortadan kalkmaktadır. Renkler ve lekeler üst üste gelerek, belirli biçim ve yüzey oluşumunu sağlamaktadır. Böylece renk birliktelikleri, açık-koyu renk kontrastları, resimsel dengeler önem kazanmaktadır. Soyut resmin denge ilişkilerinde belirleyici olan öğeler, içsel duyarlılıkla harmanlanarak daha bütüncül olan bir sanat anlayışına doğru yol almaktadır. Müzikte bir araya gelen tınılar resimlerde ifade bütünlüğüne dönüşmektedir. Sanat tarihinde farklı zaman dilimlerinde sanatçıların eserlerinde zaman zaman müzik etkisi görülmektedir.Paul Klee, Piet Mondrian, Henri Matisse, Wassily Kandinsky'de müzik etkisinin görüldüğü eserlerle karşılaşılmaktadır. Renk değerleri ve kompozisyon öğelerinin farklılaştı̆̆ı, müziğin çağrışımsal ilişkileri sanatçıları etkilemektedir. Sanatçılar üretimlerinde tınıları kendi süzgecinden geçirerek, ritmi kurguyla birlikte ifade etmektedir.

Ritmik hareket, nota yazısı, polifoni (Klee bunu resimde eşzamanlılık anlamında kullanıyor), çeşitleme, füg vb. Klee'nin Bauhaus'da verdiği derslerde bilimsel kesinlikle incelediği konular. Çoğu resimlerinde de bu çalışmaların izlerini sürdürebiliyoruz. Kimi zaman Klee, resimlerine müzikle bağlantılı adlar veriyor; "Kırmızı Füg", "Bach Stilinde", "Koral ve Manzara" vb. Bunu okuyan, müziğe yabancı olsa da müzikle bir ilişki arayacaktır resimde. Ama müzikle bağlantı kurmak ya da müziğin biçimlendirme öğelerini bulmak olanaklı (İpşiroğlu, 2000: 120).

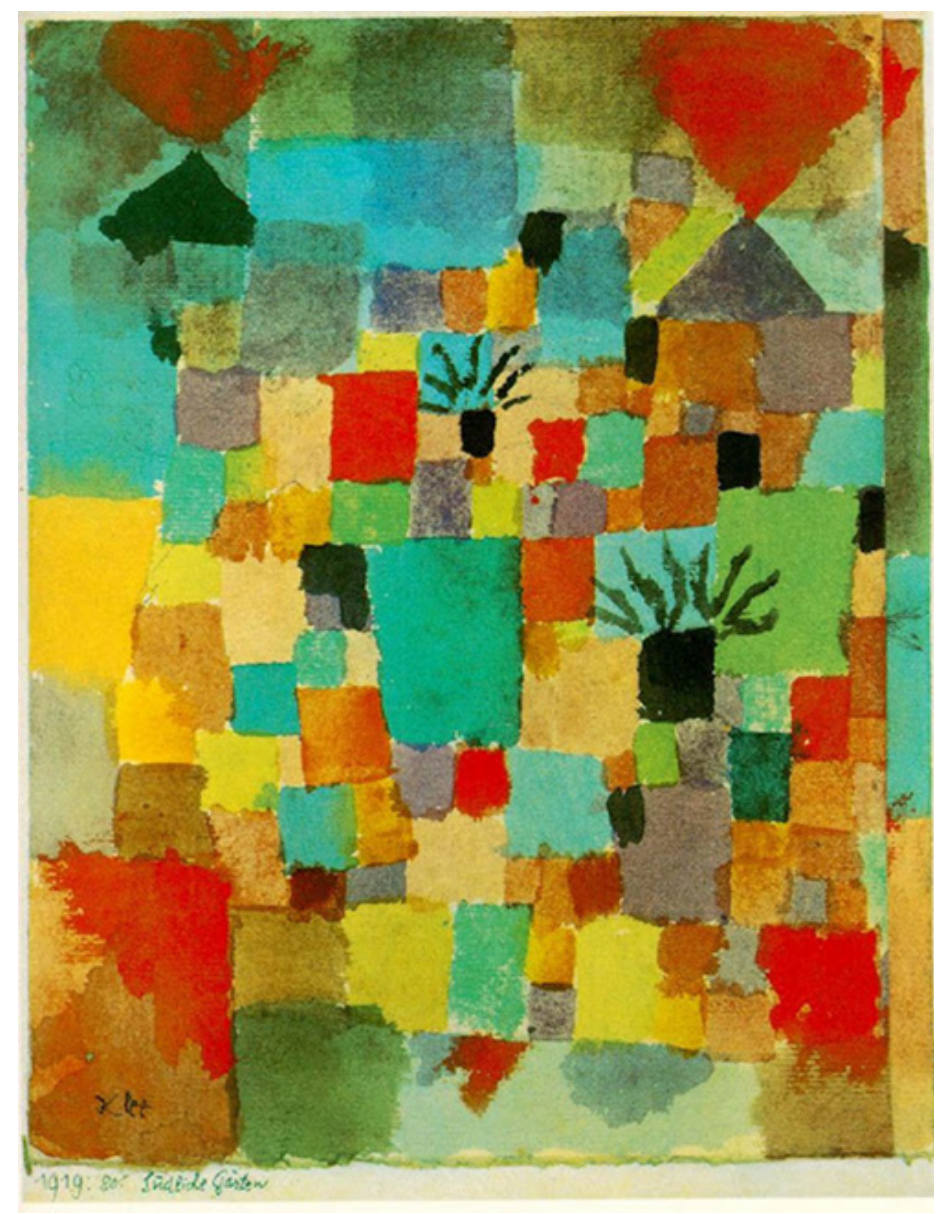

Görsel 3. Paul Klee, "Southern (Tunisian) Gardens", 1919

Paul Klee'nin "Southern (Tunisian) Gardens" isimli çalışmasında görülen geometrik formlar, formların küçüklük ve büyüklük ilişkileri dikkat çekmektedir. Eserin genel bütünlüğündeki dengelerine bakıldığı zaman ritimsel ilişkiler de gözlenmektedir.Ayrıca boyanın şeffaf geçişleriyle, armonilerdeki uyum, eserin genel bütünlüğüne de katkı sağlamaktadır. Eserdeki ritim duygusunun hissedilmesini sağlayan önemli taşıyıcı öğe ise renklerin seçimi ile de ilgilidir (Görsel 3).

Müzik sanatında bu gelişmeler yaşanırken ressamların müziği görselleştirmeye yöneldiği bu dönemde, birçok yağlıboya ve karakalem çalışmaları olan Schoenberg de müziğin yanı sıra, dışavurumcu resim alanında eserler vermiștir. Schoenberg'in çalışmalarının etkisiyle Klee ve "Blue Readers" (Mavi Atılır) Grubu soyut formlar- 
dan oluşan renk doğaçlamalarındaki etkilerle müziğe koşut bir uyum yaratmışlardır. Bunun yanı sıra Johanne Sebastian Bach yapıtlarındaki müziksel yapılar, birçok modern ressamın yapıtında, konu, biçim, içerik ve yapı unsurları olarak yer alarak yenidenüretilmiştir. Aynı zamanda ressamların yapıtlarına fugue, sonat, sinfoni gibi isimleri vermeleri ile birlikte, renk orkestrasyonu, armonik kompozisyon gibi müzikle ilgili terminolojik yaklaşımlar, resim sanatında da kullanılmış ve böylece müziksel verilerin resim sanatında yeniden üretildiği görülmüştür(Önal, 2018: 3)

Mondrian ise ritmik duyarlılığı yakaladığı eserlerinde ritmin soyut resimdek alan ilişkileri ve renk ilişkileri üzerinde daha çok durmaktadır. "Brodway Boogie-Woogie" isimli eserinde caz tınılarının etkisi, ruhun ve biçimlerin kazandığı özgürlük, ritmik bir evrende bulușmaktadır. Geometrik form iliskilerinin ve renklerin ritimle buluştuğu görsel dilin biçimlendirilmiş öğelerle buluşmasına tanıklık edilmektedir. Temel renkleri kullandığı eserinde, dikey ve yatay hareketlerle oluşturduğu kompozisyonunda ritmin, hareketin, biçimsel ve yalın olanın anlatım diline tanıklık edilmektedir.

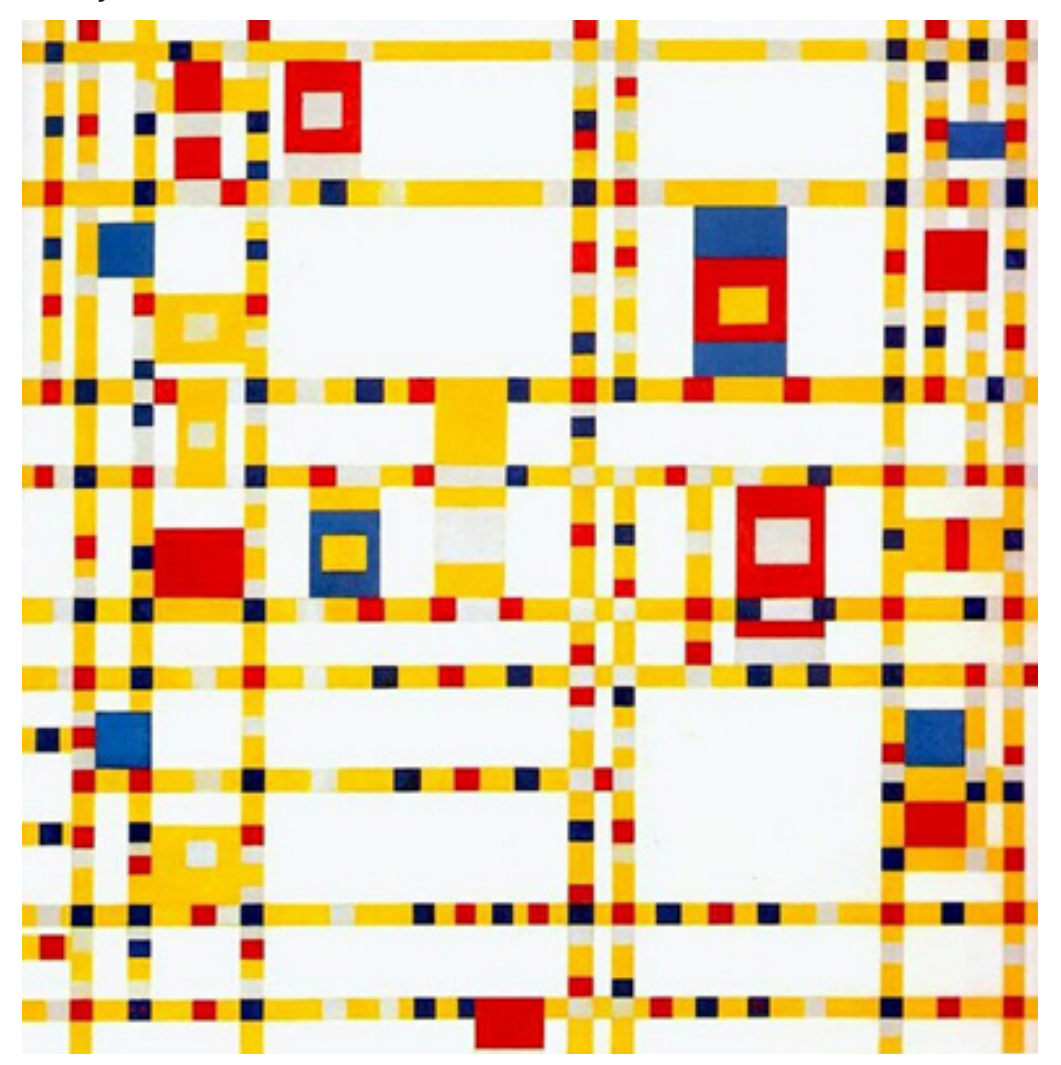

Sanatçılar, müzikte duyumsadıkları güçlü etkiden resimde de yararlanmaya giderler. Soyut bir yapıya sahip olan müzik, sanat dalları içinde güçlü etkisini her daim göstermiştir. Soyut sanatla beraber ressamlar müzikten daha verimli bir şekilde yararlanma olanağı bulur. Böylelikle resim sanatındaki soyut anlayış müziği imgede aramada büyük kolaylık sağlar. Müziğe duyarlı ressamların sanat anlayışları içerisinde müziği konumlandırışları büyük farklııılar taşır. Bu soyut olguyu resim yüzeyine aktarışları her sanatçının kendi sanat anlayışılla şekillenir. Türk resminde de müziksel anlayış benzerlik göstermekle beraber süreç 1950 sonrasına tekabül eder (Aktan, 2012: 4).

Zeki Faik İzer ise müzik etkisiyle oluşturduğu soyut dışavurumcu eserlerinde müziğin ritmindeki iniş çıkışlarına göre eserini biçimlendirmektedir. Leke, çizgi ve renklerin dağılımı müzik eşliğinde şekillenmektedir. Lekese dağılımlarında ise özellikle renklilik göze çarpmaktadır. Giray'ın da belirttiği gibi müziğin etkisini fırça hareketlerine yansıtmaktadır.

1970 yılında başlayan kolaj çalışmalarında renk, plan ve motif anlayışıla Matisse hayranlığının esinlerini yansıtır. Büyük tuvallerde dinlediği müziğin etkisini yansıtan fırça darbeleri ya da akışkanlığıyla dokunan çok renkli soyut anlatımlar Zeki Faik'in sanatının temelini oluşturur. Bu dönem içinde, canlı ve tek renkli pürüzsüz düz yüzeylerle çatışkılar oluşturan girift çizgisel bölümlerin dinamizmini yansıtan kolajlar da üretir (Giray, (t.y.):216)

Sanatçının eserlerindeki soyut yönelimler ve hareketli fırça tuşlarının birlikteliği resmin ana taşıyıcı öğesi olan kompozisyona hizmet ederek, renkli, hareketli ve müzik etkisi hissedilen eserlere dönüşmektedir. Müzikte yer alan ritimsellik ve çok seslilik sanatçının eserlerinde karşıı̆ını bulmaktadır. Özellikle müzik etkisini hissettiren ve eserlerin isimlerine yansıyan çalıșmaları arasında Beethoven'in sanat eserinden etkilendiği "Missa Solemnis" ve "Brahms'la Double Concerto" isimli eserleri bulunmaktadır. Nesnelerin somut hallerinden kalan izler; lekelerle belirli ipuçları ve imgeler oluşturarak, daha derinliği olan bir içerik oluşturmaktadır. Sanatçı eserlerinde sınırlandırmaları ortadan kaldırarak, zihnini serbest bırakarak ve içgüdüsel jestlerle, rastlantısal olan bir üslubun ortaya çıkmasını sağlamıştır. Başı ve sonu belirli olmayan serüven; enerjisi yüksek boyalı alanlar, ritmik ve renkli itkilerle, izleyiciyi de heyecanlandıran bir ilişki oluşturmaktadır. Ruhsal gerçeklik, renk, biçim ve yer yer belirgin hale gelen öğelerle, estetik algımızı farklı bakıs açılarına yönlendirmektedir. Tonların farkılıaşan nüansları, pentürel ilişkileri, yüzeylerdeki iniş ve çııışları, resim yüzeyinin özgür bir alan oluşturmasına olanak sağlamaktadır.

Görsel 4. Piet Mondrian, "Brodway Boogie-Woogie”, 1942 


\section{Zeki Faik İzer ve "Kuşlar"}

Zeki Faik eserlerinde biçim, renk, leke etkisi ve psikolojik ifade dili dikkat çekmektedir. Yansımalar, duyguların içselleştirilmesi, boya kullanımı, biçimin tek tek yansımaları rengin işlevi ve hareketleriyle, tonlamaların beyazla çevrilmiş yapıları dikkat çekmektedir. Oldukça enerjik olan resimlerde Andre Masson resimlerinde görülen kaligrafik eğilimlerle de karşılaşılmaktadır.

Soyut, informel ya da lekeci eğilimlerin tümü, sanki onun resminde bileşkesel bir değer kazanmış ve belirli bir amaca doğru kanalize olmuş gibidir. Kendi Boşluğundaki Kuş'u da bu bağlamda yorumlamak gerekir. Renklerin açık-koyu, soğuk-sıcak etkileriyle, birbiri içinde dönendiği, bir merkezkaç gücün etkisi altına etrafa yayıldığı bu kompozisyon, isminden de anlaşılacağı gibi, bir kuşun kendi boşluğunda serbestçe, hiçbir engele takılmadan, hiçbir korku ya da kuşkuya kapılmadan uçması gibi renk beneklerinin, merkezden çevreye yayılan etkilerini, resimsel bir örgütlemeye tabi tutmakta, fırçanın yarattığı soyut izlenimleri genelleştirici bir yol izlemektedir. Bu tür müzikalite duygusu, renklerin ton derecelerine göre tabloda inişli-çıkışlı rezonanslara yol açıyor bu resimde. İlgimiz fırça tuşlarının yönlerine uygun biçimde ya bir çember çizerek geriliyor, ya da açık tonların egemen olduğu zemine doğru iniyor, sonra tekrar koyu tonların bize daha yakın durduğu ayrıntılar üzerinde yoğunlaşıyor. Burada kesinleşmiş ya da önceden saptanmış biçim formülasyonu, resme karışmıyor, aksine her şey kendi doğrultusunda çözüme yönlendirilmiş olmanın spontan etkilerini yansitıyor(Özsezgin, (t.y.): 120).

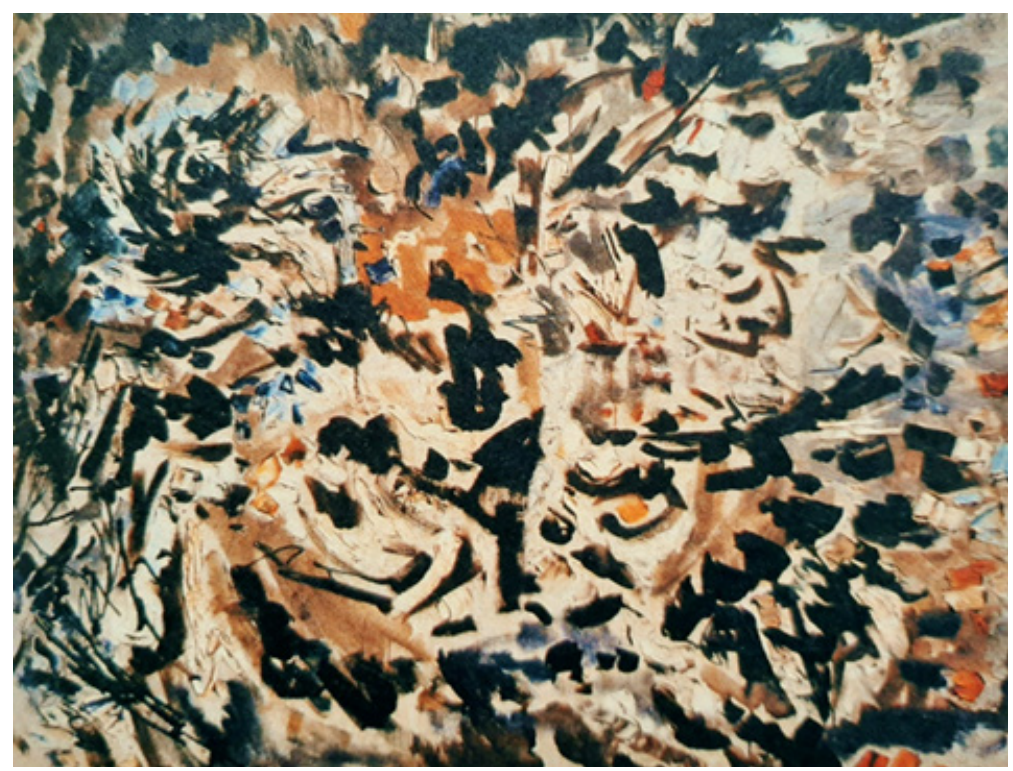

Görsel 5. Zeki Faik İzer "Kendi Boşluğundaki Kuş"
Lekeci anlayışla, soyut biçimlerin kompoze edildiği, Zeki Faik İzer'in "Kendi Boşluğundaki Kuş" adlı eserinde lekelerin bir araya gelerek kompozisyon oluşturduğu farklı versiyonlarının açık-koyu kontrastları ve kompozisyon ilişkileriyle şekillendirdiği izlenmektedir. Küçük ve büyük kompozisyon birimleri çizginin iniş çıkışları ve farklı büyüklükteki fırça tuşlarıyla harmanlanmaktadır. Açık ve nötr renklerle zemin rengi ise koyu olan fırça lekelerini öne çıkarmaktadır. Sanatçının diğer eserlerinde karşılaştığımız ritmik, lirik ve dinamik olan fırça hareketleriyle karşılaşılmaktadır (Görsel 5).

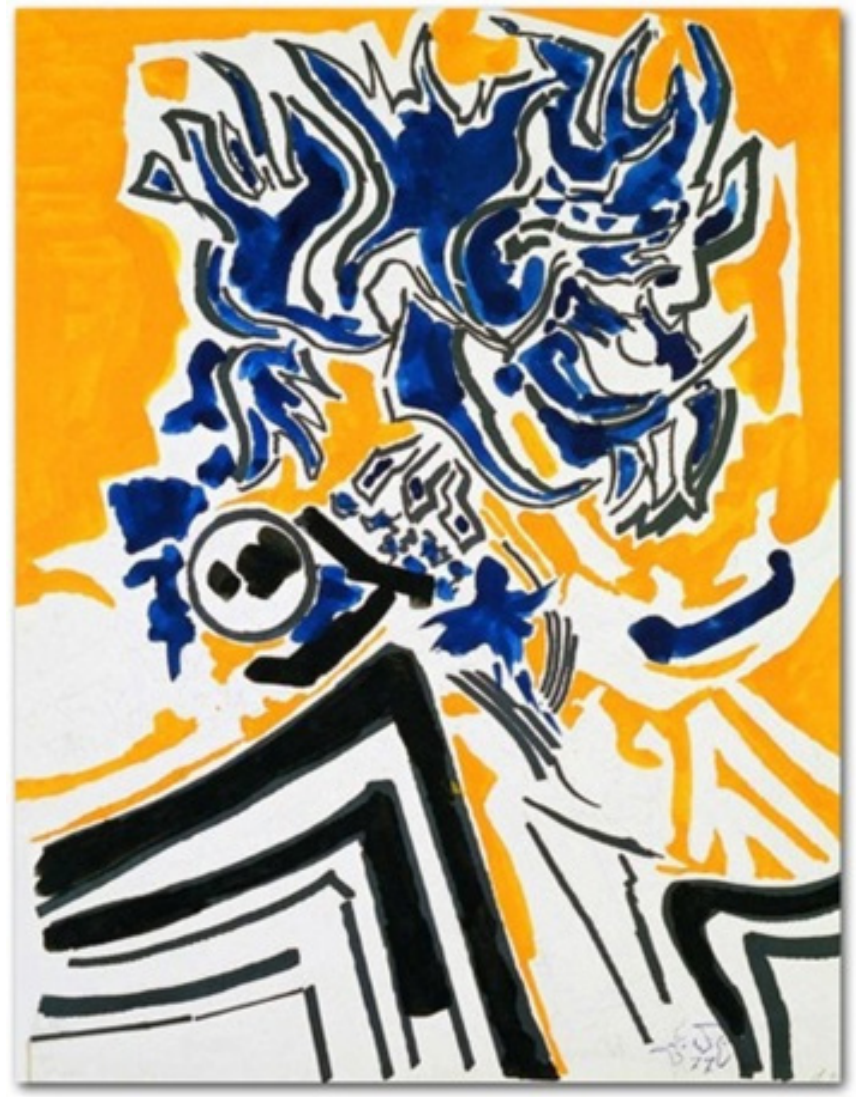

Görsel 6. Zeki Faik İzer, "Kuşlar"

Zeki Faik eserlerinde "Kuşlar" temasıyla sıkça karşılaşılmaktadır. Kuşların farklı kompozisyon ve armonilerdeki varyasyonları bulunmaktadır. Zeki Faik İzer'in "Kuşlar" isimli eseri ise daha keskin ve net olan ayrıntılara ve lekelere sahiptir. Daha soyut ve lekeci olarak ifade edilmiş eserde saf olan renkler kompozisyonun algılanmasında ve biçimlendirilmesinde önemli rol 
oynamaktadır. Üst bölümde yer alan soyutlanmış kuşlara ait olan biçimler, çizgiler ve lekeler yoğun bir kalabalığı oluşturmaktadır. Yoğun kalabalık biçimleri ise açık renkli fon ve fon içerisinde görülen beyaz boşluklar oluşturmaktadır. Zeki Faik İzer'in eserlerinde genel izlenen lirik ve ifadeci tavrın dışında daha birbiri içerisine karışmayan sade lekelerle karşılaşılmaktadır. Soyut geometrik ve daha katı olan fon ve biçimler, üst bölümde yer alan mavi renkte yer alan kompozisyon biçimlerinden oluşmaktadır. Kuşların biçimsel öğeleri, biçimlerin özü nesnelerin içsel yapısının kavranmasıyla ve özüne inilerek sadeleşmesiyle gerçekleşmektedir. Worringer'ın Soyutlama ve Özdeşleyim kitabında belirttiği gibi, soyutlamada biçimleri kavrayabilmek ancak nesnelerin özüne inmekle mümkün görünmektedir;

Görünüşler hakkındaki bilgimiz, sınır olarak görünen herşeyin aşıldığı ve birden bütün'ün göreliliğini farkettiğimiz bir noktaya eriştiğinde tamamlanmış olur. Nesneleri bilmek, onların özünün en iç çekirdeğine nüfuz etmek demektir, bu iç çekirdekte nesneler bütün sorunları ile bize kendilerini açarlar(Worringer, 1983:127).

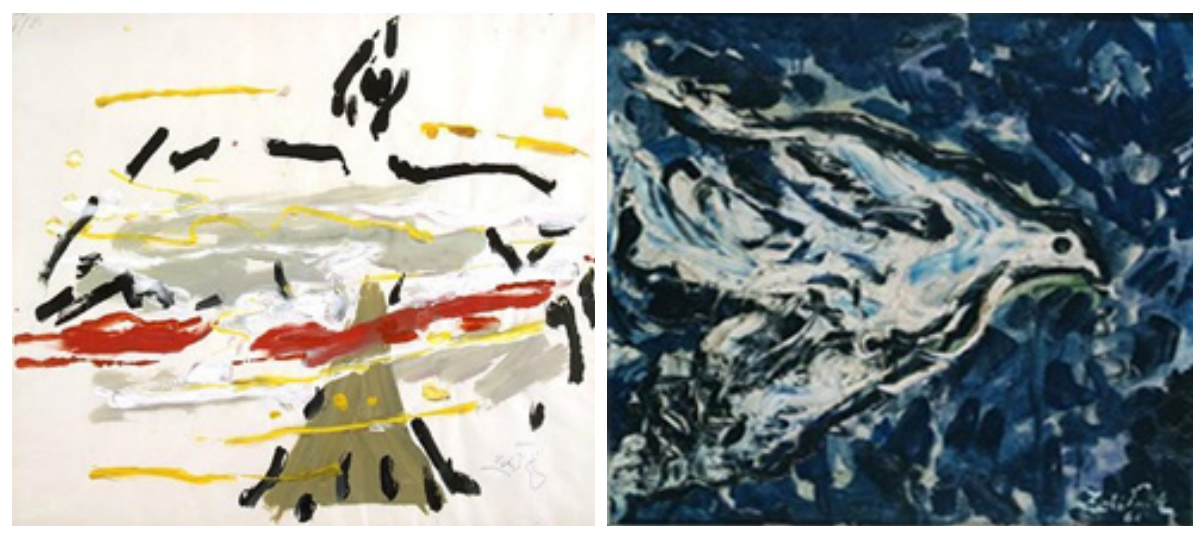

Görsel 7.Zeki Faik İzer, "Kuş" (Solda)

Görsel 8. Zeki Faik İzer, "Mavi Kuş” (Sağda)

Dışavurumcu öznel arayışlar ve içgüdüsel hareketlerle sanatçının kendi sezgi yetilerini dinleyerek üretmeye yönelmesi, kendi öz üslubunu, tekniğini ve biçimlerini oluşturması dikkat çekmektedir. Biçimsel olarak formların çarpıtıldığı ve deforme olduğu gözlenmektedir. Zeki Faik İzer'in her ik eserinde de gözlenen kuş formu soyut olan kuşlara göre rahatlıkla hissedilmektedir. Mavi rengin tonlarının çeşitlendirilmesiyle oluşan eserinde ifadeci bir bakıs açısıyla oluşan fırça tuşlarına tanıklık edilmektedir. Fırça tuşları lirik bir biçimde uygulanarak, boyanın ve formun biçimlendirilmesini de sağlamaktadır. Özellikle açıktan koyuya doğru ilerleyen ve üst üste eklenen boyalar, katmanları ve derinliği olan bir alt zemin oluşturmaktadır. Daha soyutlanmış ve sadeleşmiş kuş formu ise diğer eserindeki kuş formuna göre daha az görünürdür. Biçimlerin koyu ve açıklıkları ayıklanarak, leke ve çizgilerle tamamlanmıştır. Çizgilerin dairesel yönü dinamik bir hareket oluşturmaktadır. Açık fon rengi biçimlerin, nötr leke ve çizgilerin algılanmasını da kolaylaştırmaktadır.

Zeki Faik İzer'in diğer eserlerinde izlenen etkiler, kuşlar temalı eserlerinde de izlenmektedir.Sanatçının içselliğiyle kurulan bağ, resimsel öğelerle birlikte bir diyaloğa girerek kendiliğinden bir sürecin de gerçekleşmesini sağlamaktadır. Biçimsel ilişkiler ve renklerin dengesi, doğa temelli soyutlamalar eşliğinde coşkulu ve ritimli olan bir boya tavrına dönüşmektedir.

\section{Sonuç}

Zeki Faik İzer dış dünya algılarını kendi eser içeriğine göre biçimlendirmiş, başlangıçta daha figüratif ve nesneye bağlı olan formların zaman içerisinde daha sadeleştiği çizginin, lekenin ön plana çıtı kaybolduğu, yüzey ilişkilerinin çözümlendiği eserler oluşturmuştur. Lirik soyut, leke ve çizginin dinamizmle ilişkisinin incelendiği eserlerde, öz nitelikli formlar iç içe geçmiş durumdadır. Sanatçının figürü ve nesneyi yoğun bir şekilde araştırarak soyutlamaya yöneldiği görülmektedir. Sanatçının sadeleştirdiği realite, içsel anlatımla sanatçıya ait olan bir atmosfer oluşturmaktadır. Genellikle eserlerde, koyu-açık kontrastlar, leke, renk ve çizgi gibi plastik elemanların kullanımının düzenlendiği görülmektedir. Kompozisyonlarda sanatçının güçlü desen dili ve çizgilerinin kullanımı ritimsel bi dil ile aktarımaktadır. Sanatçının ilk dönem eserlerinde figür ve kompozisyon öğelerinde deformasyonla biçim bozmaya yöneldiği görülmektedir. Fırça tuşlarının seri ve ritmik kullanımı, hareket kavramının kendiliğinden oluşmasını sağlamaktadır. Bu nedenle sanatçının coşkusu, müzik çağrışımları ve içselliği eserlerine yansımaktadır.

Araştırmada Zeki Faik İzer'in üslubu, üslubunun kaynakları incelenerek sanatçının ilerleyen dönemlerinde daha çok resmin temel plastik öğelerinden çizgi, renk ve lekeyi yoğun olarak kullandığı tespit edilmiştir. Ozellikle başlangıç yıllarında Sanay-i Nefise Mektebi'ndeki atölye hocaları Hikmet Onat ve ibrahim Çallı'nın etkileriyle izlenimci eserlere yönelen Zeki Faik İzer, Avrupa deneyimleri sonucunda Andrea Lhote ve Otho Friezs'in lirik soyut eserlerinden etkilenerek lirik, lekeci ve soyut olan bir üsluba yönelmiştir. Eserlerinde içerikten çok biçimsel kaygılara yönelen Zeki Faik İzer; içsel duygularının da aktarımında bireyselliği ön planda tutmaktadır. Çalışmanın ilk bölümünde sanatçının henüz realiteden kopmadığı, dışavurumcu yönünün ağır bastığı eserlere yer verilmiştir. Özellikle sanatçının 
eser oluşumunda döngüsel hareketlerin ve lirizmin önem kazandığı; renk kullanımı açısından daha canlı olan renkleri daha katmanlı bir boya diliyle ifade ettiği görülmektedir. Çalışmanın üçüncü bölümünde ise sanatçının eserlerinde görülen müzik etkisi üzerinde durulmaktadır. Özellikle müziğin değişen ritmine göre sanatçının eserlerini biçimlendirme tavrı incelenmiştir.

Eserlerindeki müzik etkisinin çoşku ve neşeyle çözümlendiği tespit edilmiştir. Sanatçının kuşlar ile ilgili olan eserlerine yer verildiği dördüncü bölümde ise farklı yıllara ait olan Kuş eserlerinin biçimsel ve eser analizlerine yer verilmiştir. Sonuç olarak, Zeki Faik İzer'in figür, natürmort, kuşlar, müzik ve dans temalı eserlerinde objeler birer rehber olarak yer alırken, daha çok soyutlanmış biçimler objelerin temsillerini yansıtmaktadır. Kendiliğinden oluşan lirik anlatımda özellikle sanatçının son dönemlerinde objelerinin ree görünümünün oldukça sade haliyle izleyiciyle buluştuğu görülmektedir. Soyut lirik dışavurumcu ve lekeye dayalı olan eserler; serbest boya tavrı ve kullanımıyla ifadeci yanı güçlü olan bir dile dönüşmektedir. 


\section{Kaynakça}

Akdeniz, H. (1990). Çağdaş Resim Sanatında Kuram (Düşünce Boyutu) ve Türk Resim Sanatına Yansıması Üzerine Bir Araştırma. Dokuz Eylül Üniversitesi Sosyal Bilimler Enstitüsü Doktora Tezi.

Aktan, B.(20/2). Türk ve Batı Resminde Müziksel İmge Çözümlemesi. Işık Üniversitesi Sosyal Bilimler Enstitüsü, Yüksek Lisans Tezi.

Giray, K. (t.y.). T. C. Ziraat Bankası Sanat Koleksiyonu, I. Cilt. Yayınlayan: T. C. Ziraat Bankası A.Ş. Genel Müdürlüğü.

İpsiroğlu, N.(2000). Alımlama Boyutları ve Çeșitlemeleri Resim. Papirüs Yayınları.

Kandinsky, W.(2005). Sanatta Ruhsallık Üzerine. Altıkırkbeş Yayınları.

Klee, P. (2007). Modern Sanat Üzerine. Altıkırkbeş Yayınları.

Önal, M.A.(2018).Müzik ve Resim İlișkisi: Resim Sanatında Müziğin Yeniden Üretimine Ilişkin Örnekler.Inonu University Journal of Art and Design (2018) ISSN: I309-9876, E-ISSN: 1309-9884

Özsezgin, K. (t.y.). Cumhuriyet'in 75. Yılında Türk Resmi. İş Bankası Kültür Yayınları.

Tansuğ, S. (1997). Çağdaş Türk Sanatına Temel Yaklaşımlar. Bilgi Yayınevi.

Tansuğ, S.(1995). Türk Resminde Yeni Dönem. Remzi Kitabevi.

Tansuğ, S.(2003). Çağdaş Türk Sanatı. Remzi Kitabevi.

Worringer, W. (1983). Soyutlama ve Özdeşleyim. Remzi Kitabevi.

\section{Görsel Kaynaklar}

Görsel I: http://www.antikalar.com/zeki-faik-izer (Erişim Tarihi: 18.08.2020)

Görsel 2: http://www.antikalar.com/zeki-faik-izer (Erişim Tarihi: 18.08.2020)

Görsel 3: https://www.tarihnotlari.com/paul-klee/ (Erişim Tarihi: 10. 12. 2020)

Görsel 4: https://www.piet-mondrian.org/broadway-boogie-woogie.jsp(Erişim Tarihi: 02.0I.202I).

Görsel 5: Özsezgin, K. (). Cumhuriyet'in 75. Yılında Türk Resmi. İş Bankası Kültür

Yayınları, s. 121
Görsel 6: https://www.tarihnotlari.com/zeki-faik-izler/zeki-faik-izerkuslar/ (Erișim Tarihi: 16.11.2020

Görsel 7: https://www.tarihnotlari.com/zeki-faik-izler/kusfaik-izler/ (Erişim Tarihi: 16. (I.2020).

Görsel 8: http://www.artnet.com/artists/zeki-faik-izer/6 (Erişim Tarihi: 02.01.202I) Mavi kuş 